第 7 回脊髄外科教育セミナーより

\title{
末梢神経の外科
}

\section{Peripheral Nerve Surgery}

井須豊彦

Toyohiko Isu, M. D

Key words

peripheral nerve

\section{はじめに}

脳神経外科医が扱う疾患は脳, 脊髄, 未梢神経疾患で あるが，脳神経外科医にとっては，末梢神経疾患はなじ みの薄い疾患である，手足のしびれ，痛みを訴える患者 を専門に診ている春椎脊髄外科医は末梢神経疾患を知ら なければいけない.末梢神経疾患を知らないばかりに, 誤って, 脊椎脊髄の手術をしてしまうことが多いためで ある. 画像診断, 手術手技を過信している脳神経外科医 が最も注意しなければならないことであり, 両者が重複 してみられることを認識していないと, 脊椎脊髄手術の 術後成績がよくなく, 患者の手術満足度が低くなる. 本 論文では, 脊椎脊髄外科医が知らなければいけない末梢 神経外科の基本的な事項を述べる。

\section{絞扼性末梢神経障害}

絞扼性末梢神経障害とは末梢神経が勒带, 筋起始部の 腱性アーチや線維骨性トンネルなどの下を通過する部位 で，慢性的に機械的刺激を受け，神経障害を生じるもの である.末梢神経疾患の臨床症状は春椎脊髄疾患の臨床 症状と非常に類似しているため診断に際しては注意が必 要である.また, 単一軸索が 1 力所で絞扼されると, そ の末梢では障害を受けやすくなる double crush syndrome の存在も知っていなければならない. そのため, 通 常では神経症状を呈さない程度の圧迫でも症状を呈する ことがある。絞扼性末梢神経障害の代表的な疾患は手根
Table 1

\begin{tabular}{|c|c|}
\hline 種類 & 発生数* \\
\hline 肩甲上神経 & 8 例 \\
\hline \multicolumn{2}{|l|}{ 正中神経 } \\
\hline 回内筋症候群 & 7 例 \\
\hline 前骨間神経症候群 & 11 例 \\
\hline 手根管症候群 & 151 例 (51\%) \\
\hline \multicolumn{2}{|l|}{ 尺骨神経 } \\
\hline 肘部管症候群 & 84 例 (28\%) \\
\hline 尺骨管症候群（Guyon 管症候群） & 7 例 \\
\hline 橈骨神経（後骨間神経症候群） & 14 例 \\
\hline 大腿外側皮神経（感覚異常性大腿痛症） & 2 例 \\
\hline 総腓骨神経 & 1 例 \\
\hline 後脛骨神経（足根管症候群） & 12 例 \\
\hline 底側趾神経（Morton 病） & 1 例 \\
\hline
\end{tabular}

管症候群と肘部管症候群であり, 長野のデー夕 (Table 1) では 298 例中，手根管症候群 51\%，肘部管症候群 28\% の頻度でみられている11).

橘の 2004 年以降の手術症例 686 例の検討では, 手根 管症候群 50\%, 时部管症候群 $12 \%$ であり, 足根管症候 群が $30 \%$ 高頻度にみられた。

術前診断に際しては，臨床経過ならびに特有な病歴の 聴取, 解剖学的知識に裏打ちされた診察が必要である. 臨床経過の聴取では感覚障害を初発とすることが多いこ と(異常感覚や錯感覚などのしびれ感が先行)，末梢神経 には皮膚の固有支配領域が存在することを念頭に置くべ きである. 特有な病歴の例を以下に示す。

釧路労災病院脳神経外科 $/ \bar{T} 085-8533$ 釧路市中園町 13-23〔連絡先 : 井須豊彦〕

Address reprint requests to : Toyohiko Isu, M. D., Department of Neurosurgery, Kushiro Rosai Hospital, 13-23 Nakazono-cho, Kushiro-shi, Hokkaido 085-8533, Japan 


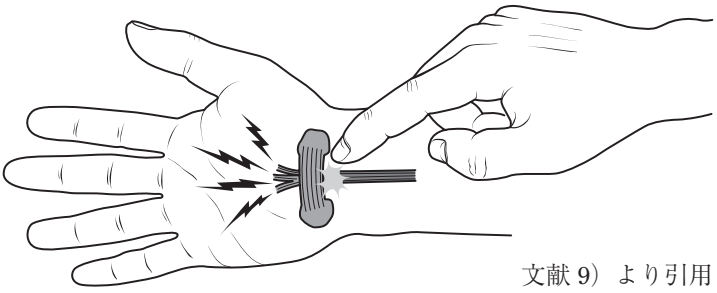

Fig. 1 Tinel 様徵候

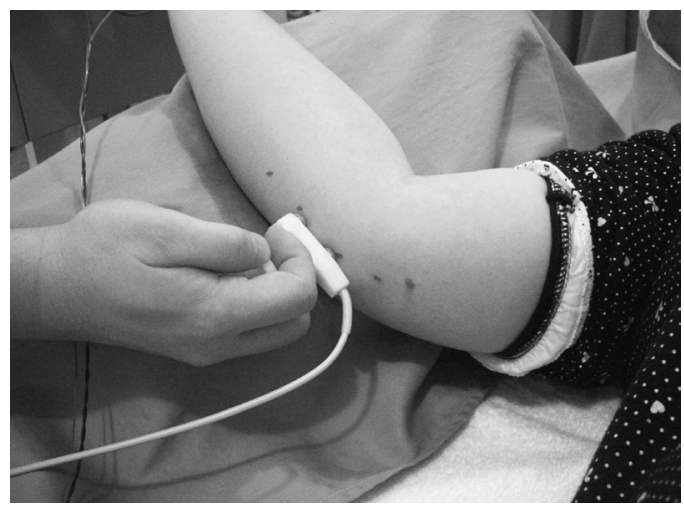

Fig. 3 Inching method

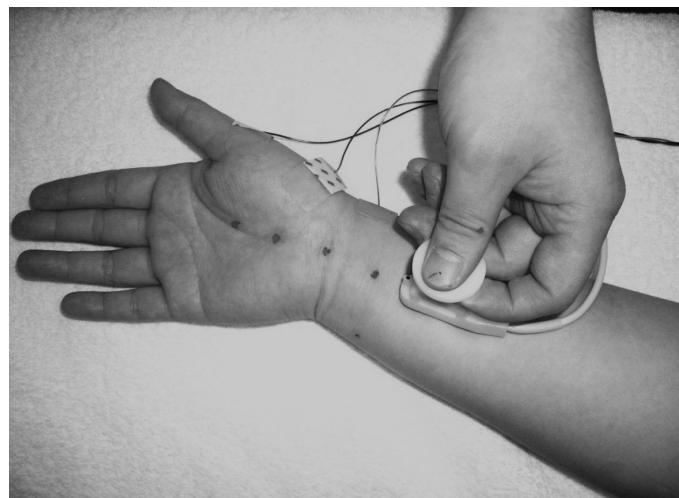

Fig. 2 神経伝導速度検査（手根管症候群例）
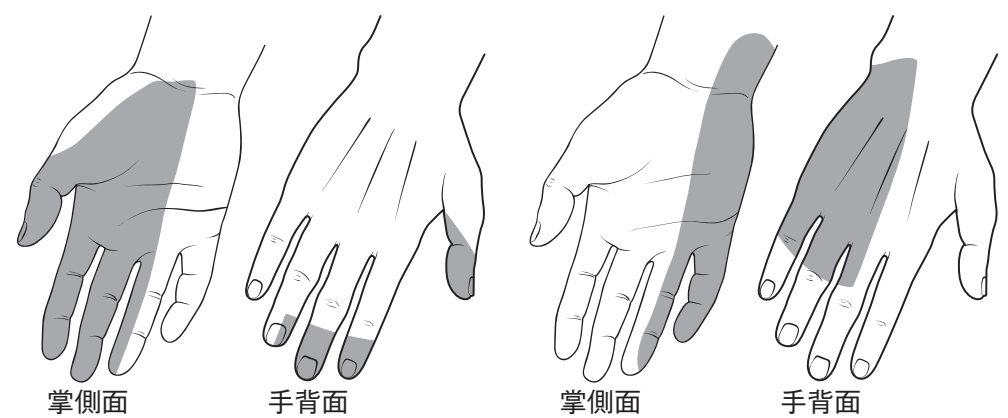

Fig. 4 正中神経皮膚支配
1）手根管症候群：夜間，手指が痛くて目を覚まし， 手を振ると楽になる

2 ) 时部管症候群：上腕骨骨折の既往の有無, 肘を曲 げるとしびれが強くなる

3 ）胸郭出口症候群：上肢を挙上すると上肢がしびれ $\tau<る$

4 ) 梨状筋症候群：座ると殿部の痛み，下肢のしびれ が強くなる

5 ）足根管症候群：夜間, 足底のしびれ, 痛み, ほと りのため眠れない

診察に際しては，感覚鈍麻，異常感覚，錯感覚の領域 を明らかにし, Tinel 様徵候があるかどうかを確認する ことが重要である. Tinel 様徴候が陽性である場合には, 障害部位を打腱器や指尖部で吋打すると，しびれ感を訴 える領域に電撃感が放散する (Fig. 1). Tinel 様徴候をみ るときには，被検神経を適度の緊張状態にして行うと痛 みが出やすい（手根管症候群では手関節を背屈，足根管 症候群では足関節を背屈, 时部管症候群では肘関節を屈 曲).

絞扼性末梢神経障害の診断には，想定される絞扼性部 位を挟んでの運動神経伝導速度検査が有用である。手根
管症候群例を示す (Fig. 2). 肘部管症候群例（Fig. 3) では病変を挟んでできるかぎり短い距離の伝導速度を計 測する inching methodを行って病変部位を同定するこ とが重要である。

\section{1. 手根管症候群}

手根管は手根骨とその上面に張った屈筋支帯で構成さ れている。手根管内を通過する正中神経が圧迫され症状 が発現する. 40〜 60 歳の中年女性に多い疾患であり，正 中神経支配領域（Fig. 4）である第 1 3 指，第 4 指橈側 のしびれ，痛みにて発症し，進行すると巧緻障害，母指 球筋の萎縮がみられる。両側性 $(80 \%)$ にみられること が多く，夜間，痛みのため目を覚ましたり，車の運転で 症状が悪化したりする。手を振ると楽になることが多い. 手根管症候群を呈しやすい疾患は肥満，妊娠，慢性血液 透析，先端巨人症，甲状腺機能低下による粘液水腫，リ ウマチ性関節炎，アミロイドーシスであり，ガングリオ ン, 血管腫や脂肪腫などの腫瘍が原因であることがある. 診察に際しては, Tinel 様徵候, Phalen test の有無を確認 しておくべきである（Fig. 5)．時に，手掌全体のしびれ や前腕，上腕の痛みを訴え，C6 神経根症との鑑別が必要 になることがある。 


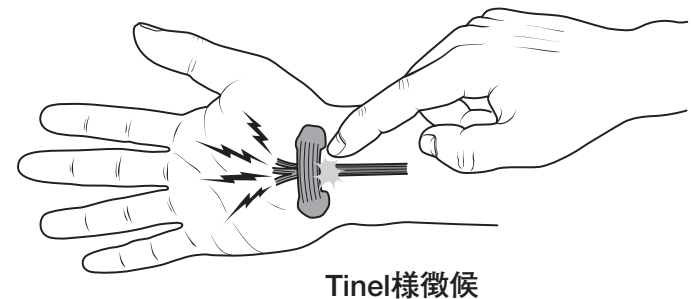

Tinel様徵候

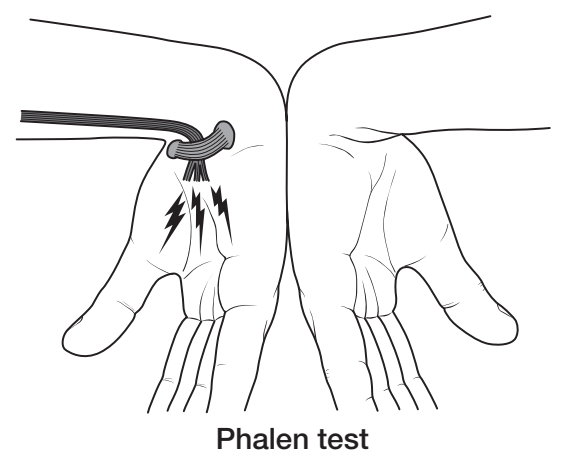

文献 9）より引用

Fig. 5 手根管症候群における誘発試験

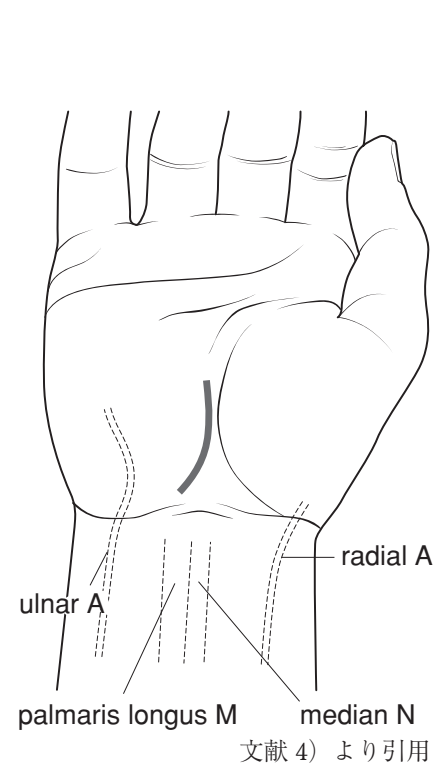

Fig. 6 皮虐切開

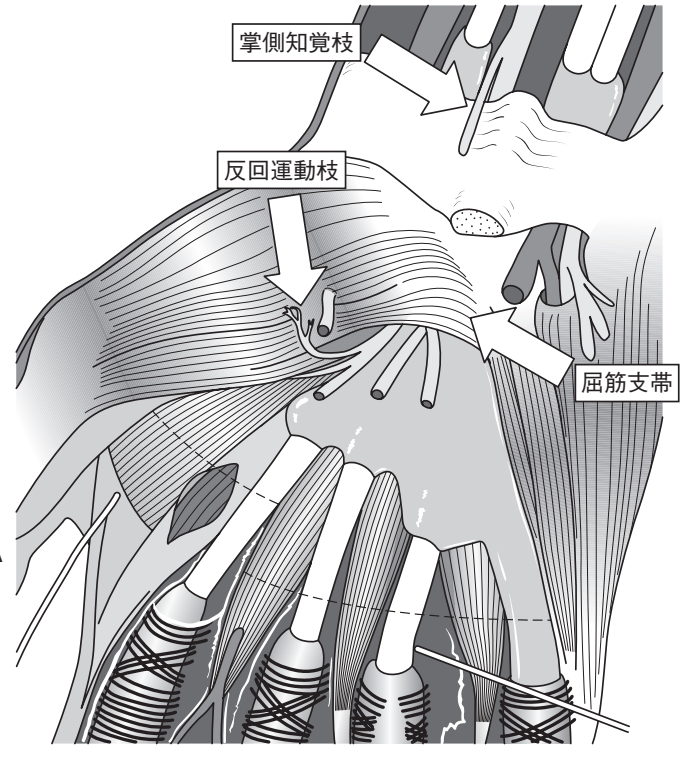

Fig. 7 手術時の注意点
保存療法（手首の安静，消炎鎮痛剂の投与）で改善し ない場合には, 手術治療を考慮する。手術法としては手 掌から前腕遠位までの皮切を行う従来法による手根管開 放術, 手掌内小切開術, 鏡視下手術が行われているが, 私は局所麻酔下の手掌内小切開術（皮膚切開は約 2.5 cm, Fig. 6) による手根管開放術を行っている. 局所麻 酔下での手術は多少, 時間がかかるが, 手術中, 症状の 改善の有無を確認しながら減圧ができる利点がある。手 術時の注意点としては, 正中神経の掌側知覚枝, 反回運 動枝を損傷しないように注意すべきである (Fig. 7)。ま た, 屈筋支带末梢側の切断に際しては, 神経周囲に脂肪 組織が観察できるまで行うことが重要である。

\section{1 ) 頚椎症の診断で手術されそうになった手根管症候 群例}

患者は 56 歳，女性で，右側手指（第 $1,2 ， 3 ， 4$ 指橈 側）先端のしびれを主訴に来院した。 5 年前より右手第 1 4 指先端のしびれがあり, 2 年前より右母指球筋の萎 縮に気がついた。他院で C $5 / 6$ レベルの䅡椎椎間板へル ニアの手術を勧められた。当科での手術を希望して受診 した.MRI（Fig. 8) では C5/6 レベルで脊髄の圧迫はみ られたが, 神経学的に右側の正中神経麻痺を認め, 運動 神経伝導速度検査では潜時の延長と振幅の低下がみられ た (Fig. 9)。夜間，しびれが強く目を覚まし手を振ると 楽になるとの話があり，手根管症候群と診断した，手根 管開放術を行ったところ，しびれは著明に改善した。

\section{2. 肘部管症候群}

肘部管症候群は肘関節部における何らかの原因により 起こった尺骨神経の絞扼性神経障害である。絞扼部位は Fig. 10 に示すように 5 カ所あるが，(2)筋中間隔，(3)上 腕骨内側上顆は肘関節屈曲時の神経亜脱臼によるもので ある．时部管の側壁は尺側手根屈筋，上壁はオスボーン 勒帯で構成されている．絞扼部位の同定は Tinel 様徵候 が誘発される部位である程度, 鑑別が可能であるが, Inching methodを用いた神経伝導速度が有効である. 30 60 歳の男性に多く，第 4 指尺側，第 5 指のしびれ， 感覚低下が最も多い症状であり, 前斜角筋症候群や澒椎 症性神経根痛 $(\mathrm{C} 7 / \mathrm{T} 1$ 病変による $\mathrm{C} 8$ 神経根痛 $)$ との鑑 別が必要である。原因としては変形性肘関節症, 上腕骨 外側上顆骨折後の外反时, 就寝時の体位（患側时を枕に して眠る), 直接の外傷, ガングリオン, 職業, スポーツ による时の過度の使用, 特発性もあるが変形性肘関節症 が最も多い. 病歴の聴取は重要で, 肘の屈曲伸展を駆使 する仕事をしているか，小児期の肘関節骨折の既往の有 無を確かめるべきである．また，肘を曲げる動作でしび れが出現するかどうかも聞かなければならない。診察に 際しては, 肘関節屈曲試験, Tinel 様徵候の有無を確認す べきである.

手術法としてはオスボーン勒带のみを切除する単純除 圧術，上腕骨内側上顆の部分削除を加える King 法，尺 骨神経前方移行術（皮下組織または筋層間に固定）があ 


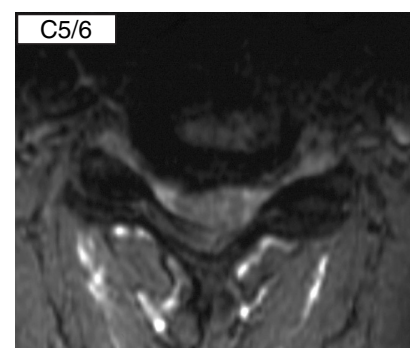

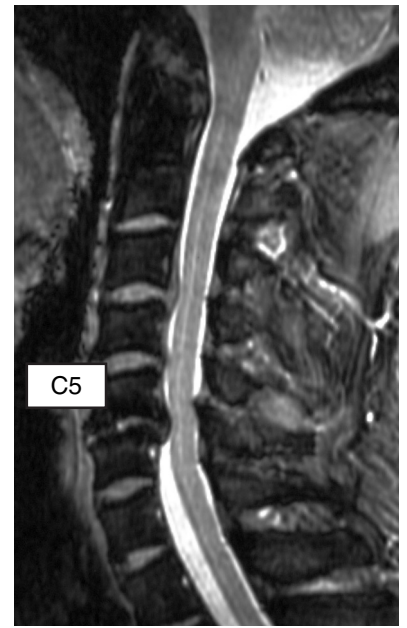

Fig. 8 MRI

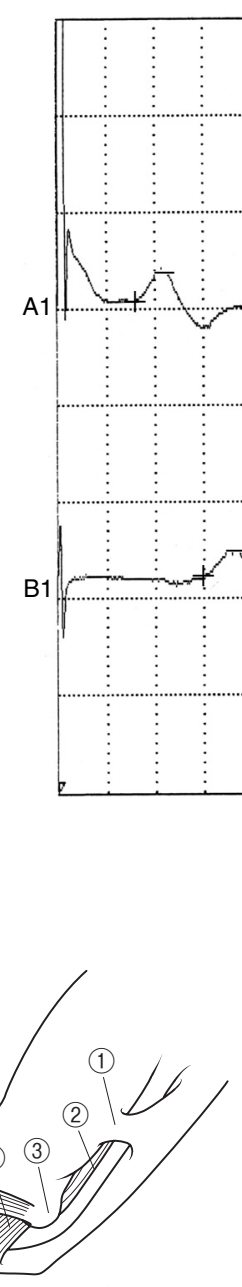

文献 2) より引用
Fig. 10 肘部管症候群における絞扼部位

肘部における尺骨神経の絞扼性神経障害を起こす部位.

(1) Struthers のアーケード.

(2) 筋中間隔.

(3) 上腕骨内側上顆.

(4) いわゆる肘部管を構成する結合織または epitrochleoanconaeus muscle.

(5) 尺側手根屈筋の二頭の筋膜で構成される部位 (Osbone's band).

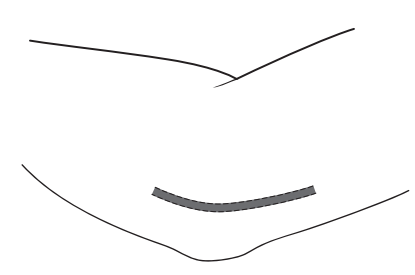

皮膚切開 (时部管症候群)
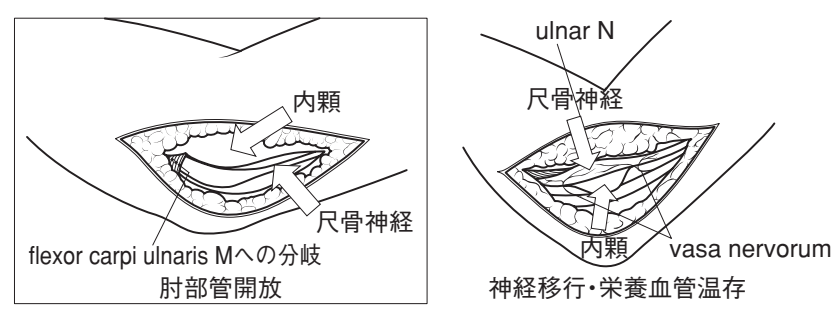

神経移行·栄養血管温存

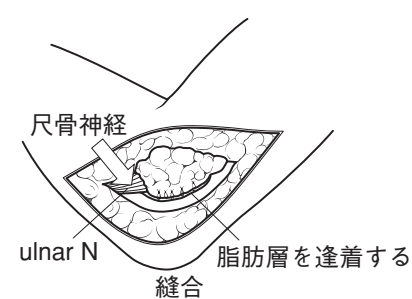

文献 4) より引用

Fig. 11 尺骨神経前方移行術

る。尺骨神経前方移行術（Fig. 11）では確実な除圧を行 うことができるが，時に全身麻酔を必要としたり，手術 操作が複雑である欠点がある。単純除圧術は簡便な手術 法であり，適応を選べば良い手術法である。

\section{3. ギオン管症候群 (Fig. 12)}

ギオン管症候群は, 手掌部での尺骨神経深枝麻痺であ
る. 第 4,5 指虫様筋, 骨間筋, 母指内転筋麻舫を起こ すが感覚障害を欠く（しびれで始まることょりも筋肉の 瘦せで始まること）が多い. 非常に珍しい。

\section{4. 胸郭出口症候群 (Fig. 13)}

胸郭出口の部位で腕神経叢または鎖骨下動脈, 静脈が 圧排されて症状が出現するものである. 頚肋, C7 横突 


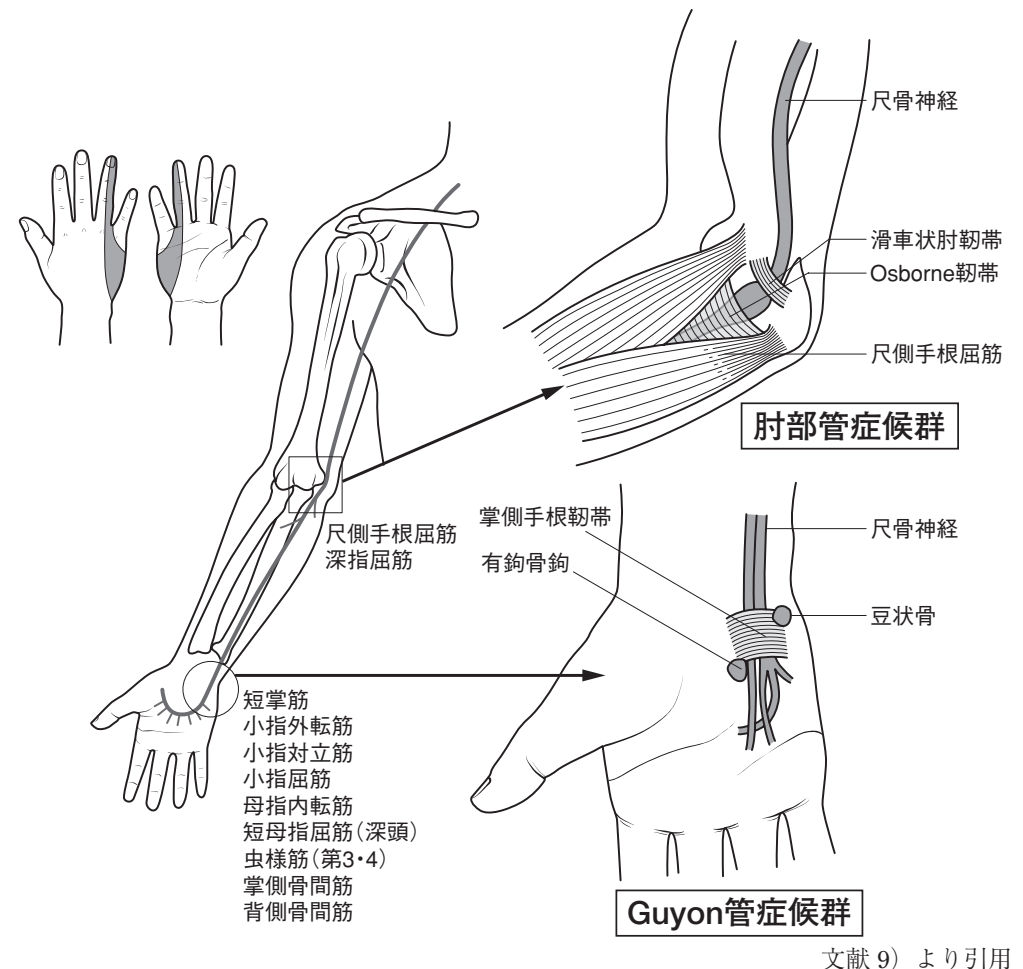

胸郭出口部の解剖

(1)前斜角筋，(2)中斜角筋，(3)鎖骨，

(4)第 1 肋骨, (5)腕神経叢, (6)鎖骨下

動脈, (7)鎖骨下静脈, 8)小胸筋.

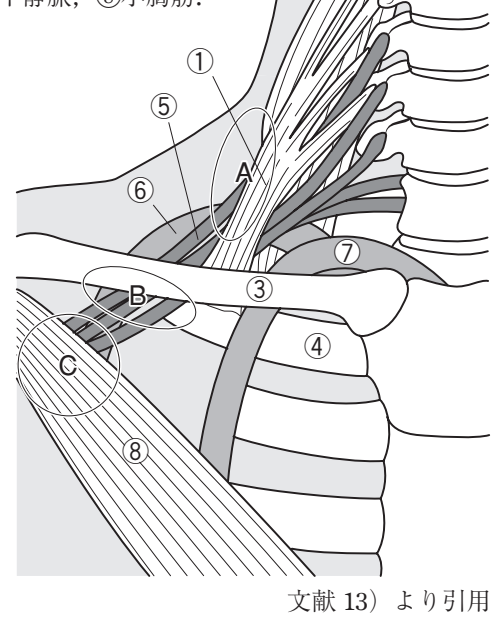

Fig. 13 胸郭出口症候群（絞扼部位）

A：前斜角筋症候群；第 1 肋骨と前，中斜角筋で構成 される三角部.

B：肋鎖間隙症候群；第 1 胁骨と鎖骨が交差する部 位.

C : 小胸筋症候群; 小胸筋と胸郭前壁の間.

Fig. 12 尺骨神経麻痺

尺骨神経の運動・知覚支配と絞扼部位。尺骨神経の絞扼部位は肘部管と尺骨神経管 (Guyon 管) である．时部管症候群では尺側手根屈筋と環・小指深指屈筋以下の尺骨神経 支配が麻盘する。尺骨神経管症候群では小指外転筋以下の尺骨神経支配筋に麻瘏が発現す る. 尺骨神経管症候群の知覚障害は掌側の固有支配領域のみに存在する.

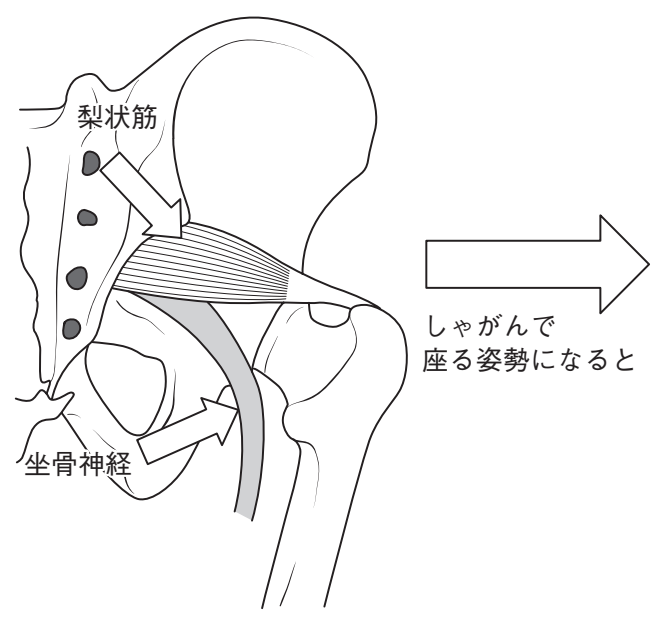

Fig. 14 梨状筋症候群の発症メカニズム

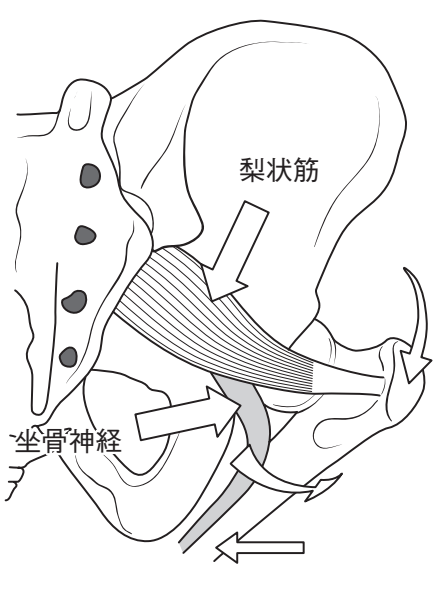

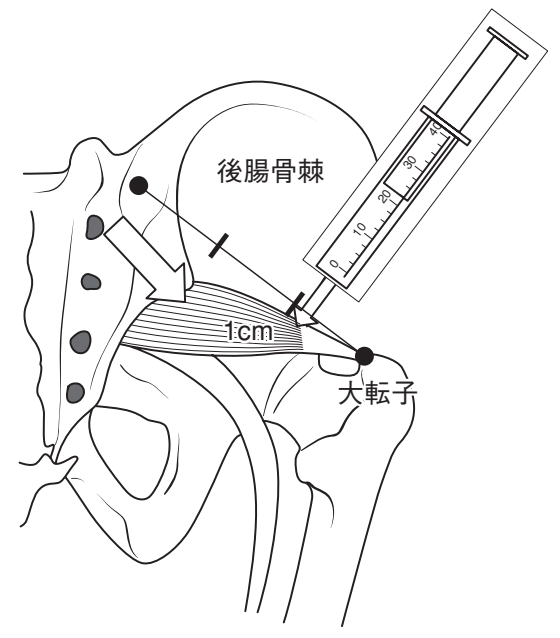

Fig. 15 梨状筋ブロック療法
起肥大，第一肋骨異常，鎖骨異常，なで肩を合併するこ とがある，絞扼部位は 3 力所あり，前斜角筋症候群（第 1 肋骨と前, 中斜角筋で構成される三角部で絞扼), 肋鎖 間隙症候群（第 1 肋骨と鎖骨が交差する部位で絞扼）, 小胸筋症候群（小胸筋と胸郭前壁の間で絞扼）と呼ばれ ている. 上肢脱力, しびれ, 冷感, レイノー現象, 筋萎
縮など多彩な症状を呈する。しびれは上肢の尺側に強い 場合が多い。腕神経叢のうち C8-T1 支配の皮虐領域, 筋の症状を呈する，重いものを持ったり，腕を上げると 症状が悪化し，橈骨動脈の拍動が減弱する。

保存療法としては，消炎鎮痛剂の投与，誘因となる姿 勢や労作を避けること，肩挙上訓練が行われている。手 


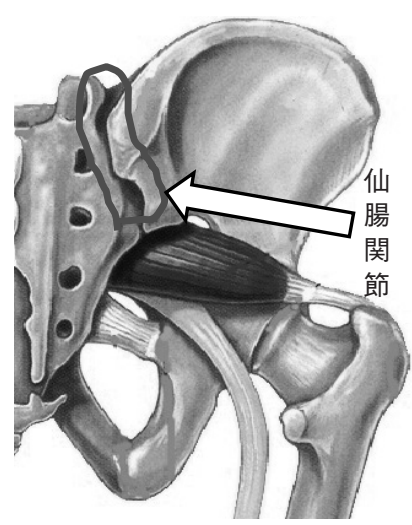

Fig. 16 仙腸関節障害

仙腸関節部を指で押すと痛い one finger test.

術は保存療法で症状が改善しない場合に考慮される。手 術法としては, 前斜角筋の部分切除を行う方法と第 1 肋 骨を切除する方法がある。

\section{5. 感覚異常性大腿神経痛}

大腿外側の異常感覚を示す感覚異常性大腿神経痛は鼠 径勒带部での外側大腿皮神経の絞扼性神経障害であり, 運動麻痺を伴わない特徵を有する。症状としては, 外側 大腿皮神経領域である大腿外側にしびれがあり，上前腸 骨棘直下の鼠径勒帯部に著明な Tinel 様徵候 (矢印) を認 める. 原因としては, きつめのガードル, 腹臥位手術後 にみられることが多いが，まれに骨盤内の悪性腫瘍が認 められることもあり，注意が必要である。また，L2，L3 神経根痛を呈する春柱管内病変 (ヘルニア, 春柱管狭窄 症など）との鑑別が必要である，治療としては，消炎鎮 痛剂や神経ブロックが有効であるが，効かなければ，神 経剝離術を考慮すべきである。

\section{6. 梨状筋症候群 (Fig. 14)}

坐骨神経の絞扼性末梢神経障害であり, 坐骨神経が骨 盤出口部で何らかの原因（外傷, 各種腫瘍など）により 梨状筋の圧迫や刺激を受けて疼痛が惹起されている状態 である. 㹨義の意味では梨状筋の解剖的破格あるいは肥 大や躲痕といった梨状筋自体が原因といわれている。大 腿が内旋して梨状筋が伸張されると総腓骨神経が筋間で 絞扼され, 症状を呈する。症状は殿部痛, 下肢痛 (多く はふともも，ふくらはぎの裏側）である。座位にて症状 が悪化することが多い. 坐骨部が当たるような姿勢がと れず，患側の殿部を浮かせることが多い，橘は，(1)脊柱 管内病変の存在にかかわりなく坐骨神経痛を示寸症例, (2)明確な根症状を呈さないもの, (3)梨状筋にトリガーポ イントがみられるもの, (4)ラセーグ徵候が除性なものを 疑診症例と考えた。橘の拡大診断基準を用いると，きわ

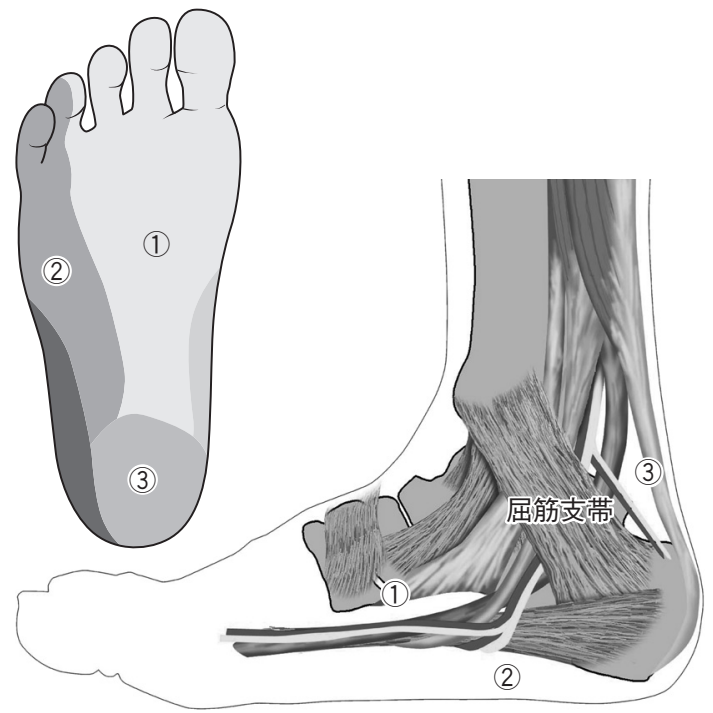

Fig. 17 後脛骨神経の走行と支配領域 (1)内側足底神経，(2)外側足底神経，(3)踵骨枝.

めて多くの症例が存在することがわかる.

治療としては，梨状筋の丞縮を取り除く梨状筋ス卜 レッチ運動, 梨状筋ブロック（Fig. 15）が有効である. 後腸骨棘と大転子を結ぶ線外 3 分の 1 のところの $1 \mathrm{~cm}$ 下の部位に針を刺し，骨盤にあて $2 \mathrm{~cm}$ 引いたところで 局所麻酔薬（1\%リドカイン） $10 \mathrm{ml}$ を注入する。橘によ れば，10\%位の症例が保存療法の効果がなく, 手術（梨 状筋の停止部で切離を行う梨状筋切断術）が施行されて いる.

\section{【仙腸関節障害】(Fig. 16)}

仙腸関節障害は絞扼性末梢神経障害ではないが, 腰痛 の鑑別診断として重要である。仙腸関節にさまざまな原 因で負担がかかると関節のズレが生じ, 痛みの原因とな る. 特徵的な症状は殿部痛であるが, 関連症状として下 肢の痛みやしびれを伴うことがある。座位，起立時，体 動時に痛みが悪化する特徵がある，上後腸骨棘部を押す と痛みが誘発される (one finger test)。治療としては, 骨盤バンドを使用し, 痛みが起こる姿勢（座ったり，しゃ がみ込んだり，体動時に，痛みが起こる場合が多い）を 避け，消炎鎮痛剂の投与を行う。それでも，痛みが軽減 しない場合には仙腸関節ブロックを施行すべきである。

\section{7. 腓骨神経麻瘏}

腓骨神経障害のほとんどが腓骨神経骨頭部での圧迫性 神経障害であり絞扼性障害はまれである。ハイソックス, 男物の靴下留め, ギプスを使用した後に起こりやすい. 腹臥位手術後に起こることがあり，注意が必要である。 症状は腓骨神経領域の異常感覚と下垂足である。下垂足 


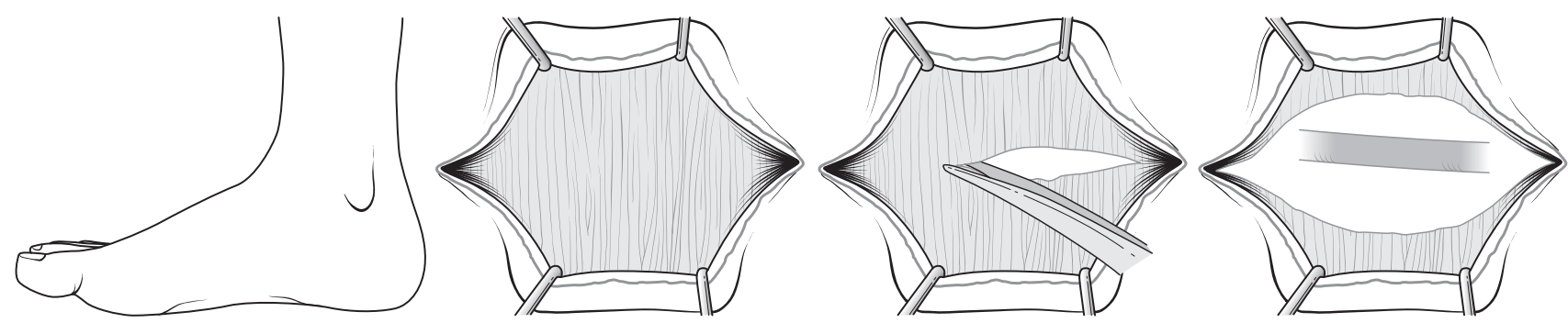

Fig. 18 足根管症候群に対する筆者の手術法

などの麻疩を伴わずに, 神経刺激症状として発現する症 例が存在することもある。そのような場合には L5 神経 根障害との鑑別が必要であり, 腓骨骨頭付近での圧痛点, 腓骨神経領域での症状の増悪, Tinel 様徵候陽性が重要 な鑑別点となる。腹臥位で行った腰椎手術後に起きた場 合には特に注意が必要である。

\section{8. 足根管症候群}

足根管症候群は足根管における後脛骨神経の絞扼が原 因である。後脛骨神経の走行と支配領域（Fig. 17）を示 す. 臨床症状は足底の痛み, しびれ（ジンジン，ピリピ リ), 冷感，ほとりであり，「餅がくっついた感じ」，「水 の上を歩いているような感じ」,「わらじをはいているよ うな感じ」がすると訴えることもある。起立, 歩行時お よび夕方から夜間にかけて症状が悪化する特徴があり， 不眠, 冷え症の原因となることもある. 足底前方部に症 状を呈することが多く, 踵に症状を伴うことはまれであ る. また, 足根管部に Tinel 様徵候を認めることが多い. 局所的要因としては, ガングリオン, 静脈瘤, 外傷, 骨 変形などが考えられるが, 特発性も半数以上含まれると の報告が多い.われわれの経験では 60 歳以上の方に多 く, 多くは両側性であり, 全例特発性であつた。

手術法としては, 屈筋支带の切開により後脛骨神経を 減圧する方法, 神経剝離術, 脂肪組織を挿入して神経, 血管を減圧する方法が行われている。神経周囲の fat に 対する操作, 神経剝離などの煩雑な操作に伴う出血は, かえって術後癒着や痒痕形成を促し, 再発の原因になる のではないかと考え, 著者は剝離操作を行っていない.

著者の行っている手術法を示す (Fig. 18). 局所麻酔下 に内顆下縁に約 $4 \mathrm{~cm}$ の弧状切開を行い, 屈筋支带を切 開して, 足根管のみを開放する手術法である。局所麻酔 下で手術を行うため, 有効な減圧操作を行うと直ちに症 状が改善し, 手術終了の指標となる。また, 神経の細か な分枝に対する操作や血管の凝固では痛みを訴えるた め, 重要な構造物を不要に損傷するリスクを回避できる 利点がある。低侵襲のため, 術後, シーネ固定や荷重制
限などの必要がなく, 術直後より歩行が可能である.

\section{釧路労災病院脳神経外科での 絞扼性末梢神経障害治療実績}

昨年度 $(2009$ 年度) の釧路労災病院脳神経外科での金 椎脊髄疾患ならびに末梢神経疾患の手術件数は 258 件 であったが，末梢神経疾患の手術件数は 83 件，32\%を 占めた. 内訳は手根管症候群 16 件, 足根管症候群 65 件, 浅腓骨神経麻疩 1 件, 上腕部での正中神経麻瘻 1 件であ つた。手根管症候群の 1 例は, 他院で頚椎症の診断で C5/6 レベルでチタンケージによる前方固定術が行われ たが症状がまったく改善しなかった症例であつた。なお， 昨年度の末梢神経疾患の手術件数は, 2008 年度の手術件 数 40 件 (14\%) より倍増していた. 今後, さらに増加 することが予想される。

\section{まとめ}

絞扼性末梢神経障害は日常診療でしばしば遭遇する疾 患である. 特徵的な臨床経過, 病歴聴取を的確に行うこ とで診断が可能であることが多い. 脊椎脊䯣疾患の診断, 治療に際しては，常に絞扼性末梢神経障害の存在を念頭 に置くことが大切である(不必要な手術を行わないため に).これから脊椎, 脊䯣外科を志先生方に一言. 未梢 神経疾患の診断, 治療を行えない医師は脊椎脊髄疾患の 治療に従事してはならないといっている医師（実は私の 末梢神経外科の師匠である西島病院脳, 脊髄, 心臓疾患 センター橘滋国先生の意見です）もいる，筆者も同感で ある。医師は画像のみに興味をもってはいけない.

\section{文 献}

1）笹森 徹, 井須豊彦, 森本大二郎, 他 : 足根管症候群の 手術治療. Spinal Surgery 22:150-152, 2008

2) 橘 滋国: 春椎脊䯣疾患と鑑別を要する末梢神経疾 患 脊椎春髄疾患と上肢末梢神経疾患の鑑別. 脊椎脊 髄 9:898-903, 2008 
3) 橘 滋国: 神経根疾患と紛らわしい未梢神経障害. 脊椎 脊髄手術一これが私の手術法一. 編著：井須豊彦. 東京, 三輪書店，2007, pp37-41

4) 橘 滋国：脳神経外科手術アトラス下巻。編集：山浦 昌, 絞扼性末梢神経障害, 東京, 医学書院, 2005, pp382387

5）橘 滋国：シビレを感じたら読む本.ブルーバックス， 東京，講談社，1993

6) Mackinnon SE, Dellon LE : Surgery of the Peripheral Nerve, Thiene Medical Publishers, 1988

7）森本大二郎, 井須豊彦, 下田祐介, 他：仙腸関節障害 · 梨状筋症候群 ·足根管症候群を合併した腰椎変性疾患 の治療経験. 脳外 37：873-879, 2009

8）村上栄一：仙腸関節由来の腰痛. 日腰痛会誌 $13: 40-$ 47, 2007
9）内藤貴文, 石井 清: 絞扼性神経障害. 新図説臨床整形 外科講座 6 (前腕, 手). 東京, メジカルビュー, 1995, pp90-99

10）長岡正宏：末梢神経障害一基礎と臨床のすべて, 肘部管 症候群。整災外 51:527-532，2008

11）長野 昭：絞扼性神経障害. 脳神経外科体系 11 (脊椎, 脊髄疾患, 未梢神経, 自律神経疾患). 東京, 中山書店, 2005, pp395-402

12) Pecina MM, Krmpotic-Nemanic J, Markiewitz AD : Tunnel Syndromes: Peripheral Nerve Compression Syndromes, 3rd ed. M M Pecina CRC PRESS, 2001

13）山口 智：絞扼性神経障害. 脊椎脊髄疾患の外科. 編 集：岩㟝喜信, 飛騨一利, 東京, 三輪書店, 2006, pp336346

14）山野慶樹：未梢神経の臨床. 東京, 医歯薬出版, 2007 